\title{
The Relation between the Awareness Level of Writing Strategies and Writing Self-Efficacy
}

\author{
Sezgin Demir ${ }^{1}$ \\ ${ }^{1}$ Faculty of Education, Firat University, Elazig, Turkey \\ Correspondence: Sezgin Demir, Department of Turkish Education and Social Sciences, Faculty of Education, Firat \\ University, Elazig 23000, Turkey. Tel: 90-532-574-9290. E-mail: sezgin.demir@firat.edu.tr
}

Received: February 6, 2018

Accepted: March 25, $2018 \quad$ Online Published: April 23, 2018

doi:10.5539/ies.v11n5p59

URL: https://doi.org/10.5539/ies.v11n5p59

\begin{abstract}
Although language is a communicational system which is based on two fundamental language skills; internal and external, it is one of the external/productive language skills together with speaking that requires a certain civilization level for a society. Writing is a tool that transfers every kind of message, dialogue, emotion, desire to stones, tablets, papyrus and finally on paper through symbols that are the result of reaching a certain level of civilization. While writing strategies enable a type of cognitive monitoring mechanism to operate; writing self-efficacy meets the need of belief regarding managing, achieving before deeds regarding performance. The purpose of this research is to determine the relation between the awareness level of writing strategies and writing self-efficacy of the secondary school students. The population of the research consists of secondary school students and the sample consists of 671 students from 5, 6,7 and $8^{\text {th }}$ grade students of four secondary schools, which were chosen from every educational region in the city of Aksaray in Turkey through simple random sampling method. Within the analysis of the data independent group $t$ test was used in terms of gender variable; and variance analysis was used in terms of grade, parental education status, and duration for reading books, watching television, and the use of internet. In order to determine the relation between the two variables Pearson correlation coefficient and for the determination of the predicting level between these two variables, simple linear regression analysis were used. As a result of the study it was seen that both the writing strategies awareness level and the self-efficacy of the female students were higher; as the grade increases, as the parental education status decreases, as the duration for daily book reading decreases and the time for watching television increases the writing strategies awareness levels of the students and their writing self-efficacies decrease. However the time for internet use did not reflect in a negative way. In addition in the research it was determined that writing strategies awareness level is a significant predictor of writing self-efficacy.
\end{abstract}

Keywords: language education, first language, writing, strategy, self-efficacy

\section{Introduction}

Language is a communication focused socialization tool, which is very complicated and it is very difficult to make a definition. Language is a contract and convention tool (Saussure, 1998) and on the other hand language competence is only peculiar to humans and it penetrates to our determined ideas and our perception deeply in accordance with our common biologic nature (Chomsky, 2009). In addition to communication and expression function since it is concentric with them, its art function, which is difficult to examine, is also the subject (Martinet, 1998). Within this context the skill areas of the language, which are speaking and writing art function, based on expression shape the communication environment such as expression, call, reference, relation and meta-language functions. Besides since reading and writing skills provide more information and being inspired for social justice they strengthen the individuals and the society (Pierson, 2014). Within this context the writing can be defined as a social deed in which the writer possesses a communicational intention (Tan \& Eng, 2014). On the other hand while communication enables language users to interact with each other and help them understand what others are trying to express, the language can be understood in different ways depending on the state and context in which the expression is involved (Bahaziq, 2016).

Writing, which can be defined as transferring the structured information on the paper through various symbols, (Güneş, 2007) is a whole of will power and habits (Barthes, 2003). Writing is a complicated and compulsory task, in which some sort of skills need to be performed at the same time (Jones, 2007). Writing activity on the other hand 
is a totally complicated deed which includes many factors consists of cognitive, social and contextual factors (Van Kooten, 2016). "Writing", which is a product of artificial and external skill area, is defined as a singular invention that changes human conscious mostly (Ong, 2014). Teaching to write requires adopting different approaches since written language is separated from oral language in terms of fundamental features such as permanence, explicitness, density, detachment, organization, and slowness of production, speed of reception, standard language, a learnt skill, sheer amount and importance (Penny, 1998). Moreover day by day, with the effect of globalization, having effective writing skills in either first language or foreign language is getting important because of educational, business and personal reasons (Yamini \& Mandanizadeh, 2011).

Self-efficacy is the opinion of the individuals whether they have the required skills for achieving something (Bandura, 1994). It is related with how good the individual is at doing the required deeds in order to manage the probable situations (Bayraktar, 2016). The beliefs regarding the self-efficacy help us determine how much effort we pay in an activity, how hard we try to struggle when we encounter handicaps and how much we resist against negative situations (Tai, 2016). Self-efficacy is one of the fundamental structures in changing the ideas, attitudes and emotions of the individuals together with locus of control (Fritson, 2008). The previous successful experiences increases the student self-efficacy regarding the concerning field (Featonby, 2012). The students ask support from their teachers to develop positive self-belief for writing and as a result, this situation contributes them developing their writing skills (Jones, 2007). The teachers have an important role in self-efficacy and success of the students (Corkett, Hatt, \& Benevides, 2011). Because whether this is a recruit or expert writer, self-efficacy is a determiner in the text and the emotional and social interaction around its context (Dix \& Cawkwell, 2011). In this respect students' having high writing self-efficacy levels as the other language skills is important for language education. Not only is writing teachable, but transferring the idea to written communication is a compulsory activity, which requires several supplementary skills levels (Jones, 2007). Writing is the talent that effects and shapes the efforts and the deeds of the students in their future life (Bodnar \& Petrucelli, 2016). If the teachers, who are at the position of learning all of their lives, enrich their in-class applications, they expect these applications to be discovered by others (Yoo, 2014). In addition, the social dimension of writing assures that, writing in not only a kind of individual activity; it also includes the other participants that support as aimed reader, peer and teacher (Kathpalia \& Heah, 2011). In teaching writing since traditional strategies are not effective developing writing performances and creative thinking skills, the use of innovative teaching strategies such as brainstorming and conceptual map will be more useful (Amoush, 2015). It is thought that carrying out the teaching to write strategy based on some points will increase students' self-efficacy regarding writing skill and acquisition. For instance students' recognizing the fundamental features of a genre will enable them produce their own examples in the same genre in a more effective way (Ahn, 2012). Every stage of written expression requires the individual to be motivated in terms of memory strategies regarding the task and process, determining aim; personal evaluation, search help, sense of responsibility and self-control components (Mango, 2009). Teaching to write must focus on teaching cognitive processes that support the writing tasks like planning and arranging (Gagnon \& Ziarko, 2012) and must be carried out through student and teacher cooperation within social interaction. At this point writing technique in cooperation is recommended in student centred learning environments and other environments in which peers interact with each other as much as possible (Luna, \& Ortiz, 2013). However at this point it must be remembered that especially the feedback of the teachers will reflect on the students' behaviours and will shape their writing attitudes (Saito, 1994). In addition it is known that the type of the feedback especially the feedback based on analysis, is related to the changes later writing of the students and improves their writings as well (Vardi, 2009). On the contrary there are studies regarding giving verbal or written feedback do not create a difference in the revisions of the students concerning content, structure, grammar and style (Gulley, 2012). A research carried out on teaching foreign language indicates that the students use strategies regarding writing stage more than the strategies in the prewriting and revision stages (Maarof \& Murat, 2013). In addition it is known that teaching prewriting strategies has positive effects on the amount of the writings of the students (Shafiee, Koosha, \& Afghari, 2015).

When the literature is examined it is seen that several studies was carried out regarding writing strategies. Within the field there are researches on grouping writing (Jacobs \& Yang, 2004), students' use of the feedback strategies (Saito, 1994), planning, the effect of paraphrasing skills on the students' skills of writing articles (Faull, 2007), the students' mapping the reading and writing strategies (Ockerstrom, 2007), writing strategies based on media richness theory reflecting on writing attitudes of the students in terms of motivation, joy and worry (Lan, Hung, \& Hsu, 2011), utilizing media as a writing strategy (Ross \& Linder, 2009), the use of strategy regarding the increase of the paragraph organization and coherence by the students who have trouble in writing (Laud \& Patel, 2008), the effect of the use of prewriting strategies on writing success (Mahnam \& Nejadansari, 2012; Shafiee, Koosha, \& Afghari, 2015), and using writing strategies (Asmari, 2013) and games (Mageehon, 2011; Nelson, Schmidt \& Verbais, 2006) for decreasing writing anxiety. Also there are studies, in which writing strategies levels of the first 
language users, English learners as a foreign language and also the students who learn English as the second language are compared, (Webb, 2015), carried out on the effect of "Think Pair Share (TPS)" application on descriptive text writing skills in secondary school students (Sumarsih \& Sanjaya, 2013), the effectiveness of peer revision intervention in writing education (Cramer \& Mason, 2014), the effect of students' self-efficacy levels on the writing skill (Horn, 2007), and the use of "Self-Regulated Strategy Development" approach as a strategy in explanatory writing (Burke, Poll, \& Fiene, 2017). There are several studies within the literature on student self-efficacy regarding writing skills. Through qualitative ethnographic (Wal \& Ryan, 2014) writing conferences regarding the determination of the relation levels between the reading-writing problems and writing self-efficacies of the secondary school students, deed research regarding the determination of the relation between their writing self-efficacies (Bayraktar, A., 2013) evaluate how and why of the phenomena by its very nature in an axiological subjectivity. Also there are studies that aim to determine how writing attitudes and self-efficacies of the students affect their writing self-efficacies (Singh \& Rajalingam, 2012), the relation between writing anxiety and self-efficacy of the students (Stewart, Seifert, \& Rolheiser, 2015; Ho, 2016), the effect of structured writing strategy on composition quality (Nicholas, Menchetti, \& Nettles, 2005), the relation between keeping a diary and students' self-efficacy and locus of control (Fritson, 2008), the relation between students self-efficacy and academic performance (Featonby, 2012). In this respect it is very important to determine other variables that are related within the increase of students' writing self-efficacies. From this point of view it is thought that carrying out a research in relational scanning model to determine the relation between the awareness levels of students' regarding writing strategies and writing self-efficacies will contribute to the field.

\subsection{The Purpose of the Research}

The purpose of the research is to determine the relation between writing strategies awareness levels and writing self-efficacy levels of the secondary school students. In accordance with this general purpose it is attempted to determine whether writing strategies awareness levels and writing self-efficacy of the students differentiate significantly or not in terms of gender, grade, parental education status, daily book reading, use of internet and watching television. In addition it is aimed to determine what kind of a relation there is between writing strategies awareness levels and writing self-efficacies and at what level it is, and whether writing strategies awareness level is a significant predictor of writing skills self-efficacy.

\section{Method}

The population of this research, which was carried out in quantitative type relational scanning model, consists of secondary school students. When it was not possible to access the target population 671 students, which were chosen with stratified sampling method centring grade variable from one school each of which were chosen with simple random sampling method from 4 educational regions in the city centre of Aksaray as sub-population, consist of the sample of the study. Within researches in relational scanning model it is aimed to describe inclination, attitude and ideas within the general population upon a sample in quantity or numerically (Creswell, 2016). In addition it is supposed to understand and define the phenomenon better examining the relations and connections (Büyüköztürk et al., 2014). Within the context of study 28 scales were not involved in the evaluation due to some reasons such as marking more than one option and leaving some items blank without marking them. In conclusion totally 643 students' scales were included in the analysis. The sample consists of 335 female (52.1\%), 308 male (47.9\%); 179 5th grade (13.7\%), 190 6th grade (14.6\%), 1417 th grade $(10.8 \%)$ and 133 8th grade $(10.2 \%)$ students.

\subsection{Development of the Data Gathering Tools}

Writing Strategies Awareness Level Scale (WSAS): Within the context of the research in order to determine writing strategies awareness levels of the students firstly 32 item 5 likert type draft scale was prepared based on the literature. Afterwards this draft scale was presented to 5 academic members from Turkish education department in Aksaray, Kilis 7 Aralık and Nevşehir Hacı Bektaş Veli universities for their ideas and evaluations in terms of content validity after 5 Turkish language teachers who work in the city centre of Aksaray. As a result of the ideas and evaluations obtained from the relevant people some improvement and arrangement were made in some items of the draft scale and 4 items were decided to be removed from the scale. In this 28 item draft scale it was seen that within the pre-application preformed on 310 students correlation matrix was examined and there was more than the acceptable relation level among the items $(\mathrm{r}>.30)$, matrix determinant value was above than .0001 , multi collinear $(r>.80)$ was not observed among the items and therefore there was no need for removing any items. The KMO value of the draft scale .76, Barlett test result was measured as $1.116,183$ and these results were found significant at .05 level. In addition within the anti-image correlation matrix 3 items, of which item concurrence values were under .50 , were removed from the scale. From this point of view it was decided to carry out 
exploratory factor analysis to the rest 25 items. Considering Scree Plot graphic Varimax operation, one of the orthogonal approaches, taking 3 point as a basis in which secular value line is broken and gains a consistent inclination. As a result of the factor analysis since 8 items did not have load value and also the relation level between two factors was lower than .10 in 1 item they were removed from the scale. It was seen that all item load value of other items change between .43 and .85 therefore any other items were not removed from the scale. Within WSAS the first factor, which consists of 6 items, explains $19.05 \%$ of the total variance, the second factor, which consists of 6 items, explains $14.90 \%$ of the total variance and the third factor, which consists of 4 items explains $15.02 \%$ of the total variance. It was seen that the three factors explain $50.14 \%$ of the total variance. It can be concluded that this situation is adequate for a multi-dimensional scale. Within the reliability test carried out for 16 items in the research since item-test (total) correlation coefficients changed between .27 and .59 and there was no item of which correlation coefficient was under .20, no item was removed from the scale. For the first 6 item factor Cronbach Alpha reliability coefficient was .78, for the second 6 item factor it was .70 and for the last 4 item factor the reliability was measured as .78. For the whole scale Cronbach Alpha reliability coefficient was .83. In addition Spearman Brown reliability coefficient was .72 and Guttman split half coefficient was .72. From this point of view it can be said that WSAS is reliable.

Writing Self-Efficacy Scale (WSS): In order to determine the writing self-efficacy level of the students that take place in the research a 40 item 5 likert type draft scale was prepared. The scale mentioned was presented to 5 academic members from Turkish education department in Aksaray, Kilis 7 Aralık and Nevşehir Hacı Bektaş Veli universities for their ideas and evaluations in terms of content validity after 5 Turkish language teachers who work in the city centre of Aksaray. As a result of the views and evaluations taken from these people some improvement and arrangement was made and 5 items were removed from the scale. Within the pre-application carried out with 365 students with the rest 35 item draft scale, correlation matrix was checked and it was seen that there were several items above the acceptable relation level ( $\mathrm{r}>30)$ among the items and matrix determinant value was more than .0001, also multi collinear ( $\mathrm{r}>.80)$ among the items was not observed and therefore there was no need for item removal. The KMO value of the draft scale was .85, Barlett test result was measured as 2.050,198 and these results were found significant at .05 level. Within anti-image correlation matrix 9 items, of which concurrence values were under .50, were removed from the scale. From this point of view it was decided that exploratory factor analysis can be carried out to the rest 26 items. Considering Scree Plot graphic Varimax operation, one of the orthogonal approaches, taking 2 point as a basis in which secular value line is broken and gains a consistent inclination. As a result of the factor analysis 4 items were removed from the scale since they did not have load value. Also 3 items were removed from the scale since they were considered as overlap item because the relation level between the two factors was less than .10. It was seen that all item load value of other items change between .45 and .85 therefore any other items were not removed from the scale. In YSS the first factor, which consists of 11 items, explains $21.12 \%$ of the total variance and the second factor, which consists of 8 items, explains $19.12 \%$ of the total variance. It was seen that two factors explain $40.24 \%$ of the total variance. It can be concluded that this situation is adequate for a multi-dimensional scale. Within the reliability test carried out for 19 items in the research since item-test (total) correlation coefficients changed between .39 and .58 and there was no item of which correlation coefficient was under .20 , no item was removed from the scale. For the first 11 item factor Cronbach Alpha reliability coefficient was .82 , for the second 8 item factor it was measured as .80 . For the whole scale Cronbach Alpha reliability coefficient was .87. In addition Spearman Brown reliability coefficient was .81 and Guttman split half coefficient was measured as .81. From this point of view it can be said that YSS is reliable.

\subsection{The Analysis of the Data}

Within the research for the analysis of the personal data percent and frequency techniques were used, in the comparisons made according to the genders of the participants independent group $t$ test, and in the analysis carried out in terms of grade, parental education status, and durations for reading a book, watching TV and the use of internet variance analysis was used. In addition in order to determine the relation among the variables Pearson correlation coefficient and for the determination of the predicting relation simple linear regression analyses were carried out. In order to determine the actualization levels of the items the ranks "always" (5), "often" (4), "sometimes" (3), "rarely" (2), and "never" (1) were used. For the interpretation of the arithmetic averages the values between 1.00-5.00 were determined as "always:4.21-5.00", "often: 3.41-4.20", "sometimes: 2.61-3.40", "rarely:1.81-2.60" and "never: 1.00-1.80".

\section{Results}

Within this part of the research the findings obtained as a result of the analysis of the data are shared: 
Table 1 . The $\mathrm{T}$ test results of the students regarding writing adequacies in terms of gender variable

\begin{tabular}{lccccccc}
\hline Dimensions & Gender & $\mathrm{n}$ & $M$ & $\mathrm{ss}$ & $\mathrm{sd}$ & $\mathrm{t}$ & $\mathrm{p}$ \\
\hline \multirow{2}{*}{ Writing Strategies Awareness } & Female & 335 & 3.74 & .73 & \multirow{2}{*}{61} & \multirow{2}{*}{1.926} & .06 \\
& Male & 308 & 3.63 & .73 & & & \\
\multirow{2}{*}{ Writing Self-Efficacy } & Female & 335 & 3.94 & .65 & & & \\
\multirow{2}{*}{ Writing Adequacy } & Male & 308 & 3.75 & .68 & & 3.605 & $.00 *$ \\
& Female & 335 & 3.84 & .65 & & & \\
& Male & 308 & 3.69 & .67 & 641 & 2.885 & $.00^{*}$ \\
\hline
\end{tabular}

According to the findings in Table 1 the writing strategies awareness levels of the students do not differentiate significantly in terms of gender variable $[\mathrm{t}(641)=1.926 ; \mathrm{p}>.05]$. On the contrary it was determined that the writing strategies awareness levels of the female students $(M=3.74)$ were higher than male students $(M=3.63)$. Yet writing self-efficacy levels differentiate significantly according to gender variable $[\mathrm{t}(641)=3.605 ; \mathrm{p}<.05]$. At this point the writing skills self-efficacy levels of the female students $(M=3.94)$ are higher than male students $(M=3.75)$. Generally it can be said that there is a significant differentiation in terms of gender variable $[\mathrm{t}(641)=2.885 ; \mathrm{p}<.05]$, and girls $(M=3.84)$ consider themselves adequate regarding writing at a better level compared to boys $(M=3.69)$.

Table 2. The results of the variance analysis regarding the writing adequacies of the students according to grade

\begin{tabular}{|c|c|c|c|c|c|c|c|c|c|c|c|}
\hline Dimensions & Grade & $\mathrm{n}$ & $M$ & ss & VK & KT & $\mathrm{sd}$ & $\mathrm{KO}$ & $\mathrm{F}$ & $\mathrm{p}$ & Difference \\
\hline \multirow{5}{*}{$\begin{array}{l}\text { Writing } \\
\text { Awareness }\end{array}$} & $5^{\text {th }}$ grade & 179 & 3.69 & .73 & \multirow{2}{*}{ Between Groups } & \multirow{2}{*}{2.151} & \multirow{2}{*}{3} & \multirow{2}{*}{.717} & \multirow{5}{*}{1.332} & \multirow{5}{*}{.263} & \multirow{5}{*}{-} \\
\hline & $6^{\text {th }}$ grade & 190 & 3.77 & .72 & & & & & & & \\
\hline & $7^{\text {th }}$ grade & 141 & 3.63 & .79 & \multirow{2}{*}{ Within Group } & \multirow{2}{*}{344.053} & \multirow{2}{*}{639} & \multirow{3}{*}{.538} & & & \\
\hline & $8^{\text {th }}$ grade & 133 & 3.63 & .70 & & & & & & & \\
\hline & Total & 643 & 3.69 & .73 & Total & 346.204 & 642 & & & & \\
\hline \multirow{5}{*}{ Writing Self-Efficacy } & $5^{\text {th }}$ grade & 179 & 3.93 & .70 & \multirow{2}{*}{ Between Groups } & \multirow{2}{*}{3.645} & \multirow{2}{*}{3} & \multirow{2}{*}{1.215} & \multirow{5}{*}{$2.729^{*}$} & \multirow{5}{*}{.043} & \multirow{5}{*}{$\begin{array}{l}5-7 \\
6-7\end{array}$} \\
\hline & $6^{\text {th }}$ grade & 190 & 3.89 & .66 & & & & & & & \\
\hline & $7^{\text {th }}$ grade & 141 & 3.74 & .65 & \multirow{2}{*}{ Within Group } & \multirow{2}{*}{284.443} & \multirow{2}{*}{639} & \multirow{3}{*}{.445} & & & \\
\hline & $8^{\text {th }}$ grade & 133 & 3.78 & .65 & & & & & & & \\
\hline & Total & 643 & 3.85 & .67 & Total & 288.088 & 642 & & & & \\
\hline \multirow{5}{*}{ Writing Adequacies } & $5^{\text {th }}$ grade & 179 & 3.81 & .67 & \multirow{2}{*}{ Between Groups } & \multirow{2}{*}{2.476} & \multirow{2}{*}{3} & \multirow{2}{*}{.825} & \multirow{5}{*}{1.885} & \multirow{5}{*}{.131} & \multirow{5}{*}{-} \\
\hline & $6^{\text {th }}$ grade & 190 & 3.83 & .66 & & & & & & & \\
\hline & $7^{\text {th }}$ grade & 141 & 3.69 & .68 & \multirow{2}{*}{ Within Group } & \multirow{2}{*}{279.727} & \multirow{2}{*}{639} & 438 & & & \\
\hline & $8^{\text {th }}$ grade & 133 & 3.71 & .63 & & & & .438 & & & \\
\hline & Total & 643 & 3.77 & .66 & Total & 282.203 & 642 & & & & \\
\hline
\end{tabular}

$* \mathrm{p}<.05$.

The findings in Table 2 indicate that the awareness levels of the students regarding their writing strategies do not differentiate significantly in terms of grade variable $[\mathrm{F}(3-639)=1.332 ; \mathrm{p}>.05]$, on the contrary it indicates that as the grade increases the awareness of the students decreases. It can be stated that this situation is a result of the effect of the system which is focused on exam based studies during the passage to the secondary school especially while they are getting closer to the last grade, and they get away from experience centred paradigmatic approaches and applications. Their writing self-efficacy levels differentiate significantly in terms of grade variable $\left[\mathrm{F}(3-639)=2.729^{*} ; \mathrm{p}<.05\right]$. Scheffe, Tukey and LSD tests indicate that the differentiation is among 7 th grade $(M$ $=3.74)$, and 5th grade $(M=3.93)$ and 6th grade $(M=3.89)$. In addition as the grade increases student self-efficacy decreases. Especially it can be said that getting away from the active student centred teaching methods based on in class applications with exam anxiety is effective. Generally although there was not a significant differentiation in terms of grade variable $[\mathrm{F}(3-639)=1.885 ; \mathrm{p}>.05]$, it can be said that within upper grades the self-confidence of the students regarding writing skills decreases systematically. 
Table 3. The results of the variance analysis regarding the writing adequacies of the students according to mother education status

\begin{tabular}{|c|c|c|c|c|c|c|c|c|c|c|c|}
\hline Dimensions & Grade & $\mathrm{n}$ & $M$ & ss & $\mathrm{VK}$ & KT & $\mathrm{sd}$ & $\mathrm{KO}$ & $\mathrm{F}$ & $\mathrm{p}$ & Difference \\
\hline \multirow{6}{*}{$\begin{array}{l}\text { Writing Strategies } \\
\text { Awareness }\end{array}$} & $\begin{array}{c}\text { Not } \\
\text { Literate }\end{array}$ & 125 & 3.67 & .79 & \multirow{2}{*}{$\begin{array}{c}\text { Between } \\
\text { Groups }\end{array}$} & \multirow[t]{2}{*}{6.221} & \multirow[t]{2}{*}{4} & \multirow[t]{2}{*}{1.555} & \multirow{6}{*}{$2.919^{*}$} & \multirow{6}{*}{.021} & \multirow{6}{*}{$\begin{array}{l}\text { Not Literate, Primary, } \\
\text { Secondary University }\end{array}$} \\
\hline & Primary & 173 & 3.62 & .74 & & & & & & & \\
\hline & Secondary & 145 & 3.62 & .69 & & & & & & & \\
\hline & $\begin{array}{l}\text { High } \\
\text { school }\end{array}$ & 111 & 3.75 & .70 & Groups & 339.983 & 638 & .533 & & & \\
\hline & University & 89 & 3.90 & .73 & \multirow{2}{*}{ Total } & \multirow{2}{*}{346.204} & \multirow{2}{*}{642} & & & & \\
\hline & Total & 643 & 3.69 & .73 & & & & & & & \\
\hline \multirow{6}{*}{$\begin{array}{l}\text { Writing } \\
\text { Self-Efficacy }\end{array}$} & $\begin{array}{c}\text { Not } \\
\text { Literate }\end{array}$ & 125 & 3.79 & .74 & \multirow{2}{*}{$\begin{array}{c}\text { Between } \\
\text { Groups }\end{array}$} & \multirow[t]{2}{*}{7.946} & \multirow[t]{2}{*}{4} & \multirow[t]{2}{*}{1.987} & \multirow{6}{*}{$4.524 *$} & \multirow{6}{*}{.001} & \multirow{6}{*}{$\begin{array}{c}\text { Not Literate, Primary, } \\
\text { Secondary, H- school } \\
\text { University }\end{array}$} \\
\hline & Primary & 173 & 3.78 & .66 & & & & & & & \\
\hline & Secondary & 145 & 3.79 & .64 & Within & & & & & & \\
\hline & $\begin{array}{l}\text { High } \\
\text { school }\end{array}$ & 111 & 3.89 & .67 & Groups & 280.142 & 638 & .439 & & & \\
\hline & University & 89 & 4.11 & .55 & \multirow{2}{*}{ Total } & \multirow{2}{*}{288.088} & \multirow{2}{*}{642} & & & & \\
\hline & Total & 643 & 3.85 & .67 & & & & & & & \\
\hline \multirow{6}{*}{$\begin{array}{l}\text { Writing } \\
\text { Adequacies }\end{array}$} & $\begin{array}{c}\text { Not } \\
\text { Literate }\end{array}$ & 125 & 3.73 & .73 & \multirow{2}{*}{$\begin{array}{c}\text { Between } \\
\text { Groups }\end{array}$} & \multirow[t]{2}{*}{6.983} & \multirow[t]{2}{*}{4} & \multirow[t]{2}{*}{1.746} & \multirow{6}{*}{$4.047^{*}$} & \multirow{6}{*}{.003} & \multirow{6}{*}{$\begin{array}{l}\text { Not Literate, Primary, } \\
\text { Secondary University }\end{array}$} \\
\hline & Primary & 173 & 3.70 & .67 & & & & & & & \\
\hline & Secondary & 145 & 3.70 & .63 & Within & & & & & & \\
\hline & $\begin{array}{l}\text { High } \\
\text { school }\end{array}$ & 111 & 3.82 & .63 & Groups & 275.220 & 638 & .431 & & & \\
\hline & University & 89 & 4.01 & .59 & \multirow{2}{*}{ Total } & \multirow{2}{*}{282.203} & \multirow{2}{*}{642} & & & & \\
\hline & Total & 643 & 3.77 & .66 & & & & & & & \\
\hline
\end{tabular}

$* \mathrm{p}<.05$.

The findings in Table 3, indicate that the awareness levels of the students regarding their writing strategies differentiate significantly in terms of mother education status $\left[\mathrm{F}(4-638)=2.919^{*} ; \mathrm{p}<.05\right]$. It was determined that especially as the mother education status increases students' writing strategies awareness levels increase systematically, and the writing strategies awareness of the children $(M=3.90)$, whose mother graduated from university, were higher than the children whose mothers are illiterate or graduated from primary or secondary schools. Writing self-efficacies of the students differentiate significantly in terms of mother education status as well $\left[\mathrm{F}(4-638)=4.524^{*} ; \mathrm{p}<.05\right]$. The writing self-efficacy levels of the children $(M=4.11)$, whose mothers graduated from university, are prominently higher than the children whose mothers graduated from other educational status. Generally it is seen that self-confidence of the students regarding writing adequacy differentiate significantly $\left[\mathrm{F}(4-638)=4.047^{*} ; \mathrm{p}<.05\right]$. It can be said that as the education status of the mother increases not only the awareness of the students regarding writing strategies but also their writing self-efficacies increases and their self-confidence regarding their writing skills increase as well.

Table 4. The results of the variance analysis regarding writing adequacies of the students according to the education status of the father

\begin{tabular}{|c|c|c|c|c|c|c|c|c|c|c|c|}
\hline Dimensions & Grade & $\mathrm{n}$ & $M$ & ss & VK & KT & $\mathrm{sd}$ & $\mathrm{KO}$ & $\mathrm{F}$ & $\mathrm{p}$ & Difference \\
\hline \multirow{6}{*}{$\begin{array}{l}\text { Writing } \\
\text { Strategies } \\
\text { Awareness }\end{array}$} & $\begin{array}{c}\text { Not } \\
\text { Literate }\end{array}$ & 58 & 3.69 & .76 & \multirow[t]{2}{*}{$\begin{array}{c}\text { Between } \\
\text { Groups }\end{array}$} & \multirow[t]{2}{*}{8.408} & \multirow[t]{2}{*}{4} & \multirow[t]{2}{*}{2.102} & \multirow{6}{*}{$3.970 *$} & \multirow{6}{*}{.003} & \multirow{6}{*}{$\begin{array}{c}\text { Primary -High school, } \\
\text { University; Secondary - } \\
\text { University }\end{array}$} \\
\hline & Primary & 111 & 3.55 & .77 & & & & & & & \\
\hline & Secondary & 160 & 3.59 & .76 & Within & & & & & & \\
\hline & $\begin{array}{l}\text { High } \\
\text { school }\end{array}$ & 179 & 3.73 & .67 & Groups & 337.796 & 638 & .529 & & & \\
\hline & University & 135 & 3.87 & .71 & \multirow{2}{*}{ Total } & \multirow{2}{*}{346.204} & \multirow{2}{*}{642} & & & & \\
\hline & Total & 643 & 3.69 & .73 & & & & & & & \\
\hline
\end{tabular}




\begin{tabular}{|c|c|c|c|c|c|c|c|c|c|c|c|}
\hline \multirow{6}{*}{$\begin{array}{l}\text { Writing } \\
\text { Self-Efficacy }\end{array}$} & $\begin{array}{c}\text { Not } \\
\text { Literate }\end{array}$ & 58 & 3.76 & .70 & \multirow{2}{*}{$\begin{array}{c}\text { Between } \\
\text { Groups }\end{array}$} & \multirow[t]{2}{*}{9.770} & \multirow[t]{2}{*}{4} & \multirow[t]{2}{*}{2.443} & \multirow{6}{*}{$5.599 *$} & \multirow{6}{*}{.000} & \multirow{6}{*}{$\begin{array}{l}\text { Not Literate-University; } \\
\text { Primary - High school, } \\
\text { University; Secondary } \\
\text {-High school, University }\end{array}$} \\
\hline & Primary & 111 & 3.69 & .75 & & & & & & & \\
\hline & Secondary & 160 & 3.74 & .69 & Within & & & & & & \\
\hline & $\begin{array}{l}\text { High } \\
\text { school }\end{array}$ & 179 & 3.94 & .58 & Groups & 278.318 & 638 & .436 & & & \\
\hline & University & 135 & 4.00 & .63 & \multirow{2}{*}{ Total } & \multirow{2}{*}{288.088} & \multirow{2}{*}{642} & & & & \\
\hline & Total & 643 & 3.85 & .67 & & & & & & & \\
\hline \multirow{6}{*}{$\begin{array}{l}\text { Writing } \\
\text { Adequacies }\end{array}$} & $\begin{array}{c}\text { Not } \\
\text { Literate }\end{array}$ & 58 & 3.72 & .68 & \multirow[t]{2}{*}{$\begin{array}{c}\text { Between } \\
\text { Groups }\end{array}$} & \multirow[t]{2}{*}{8.827} & \multirow[t]{2}{*}{4} & \multirow[t]{2}{*}{2.207} & \multirow{6}{*}{$5.150 *$} & \multirow{6}{*}{.000} & \multirow{6}{*}{$\begin{array}{c}\text { Not Literate, Primary, } \\
\text { Secondary - University; } \\
\text { Primary, Secondary - High } \\
\text { school }\end{array}$} \\
\hline & Primary & 111 & 3.62 & .73 & & & & & & & \\
\hline & Secondary & 160 & 3.67 & .69 & \multirow{2}{*}{$\begin{array}{l}\text { Within } \\
\text { Groups }\end{array}$} & \multirow[b]{2}{*}{273.376} & \multirow[b]{2}{*}{638} & \multirow{4}{*}{.428} & & & \\
\hline & $\begin{array}{l}\text { High } \\
\text { school }\end{array}$ & 179 & 3.84 & .59 & & & & & & & \\
\hline & University & 135 & 3.94 & .61 & \multirow{2}{*}{ Total } & \multirow{2}{*}{282.203} & \multirow{2}{*}{642} & & & & \\
\hline & Total & 643 & 3.77 & .66 & & & & & & & \\
\hline
\end{tabular}

$* \mathrm{p}<.05$.

In Table 4, it is seen that the awareness levels of the students regarding their writing strategies differentiate significantly in terms of father education status variable $[\mathrm{F}(4-638)=3.970 * ; \mathrm{p}<.05]$. Especially it is seen that the children whose fathers graduated from primary $(M=3.55)$ and secondary $(M=3.59)$ school have awareness at low levels compared to those children whose fathers have high level of education status. Similarly writing self-efficacies differentiate significantly in terms of father education status $[\mathrm{F}(4-638)=5.599 * ; \mathrm{p}<.05]$. It was determined that the writing self-efficacies of the children whose fathers graduated from high school $(M=3.94)$ and university $(M=4.00)$ were higher than the children whose fathers have low level of education status. The general state of the students concerning their writing adequacies differentiate significantly $\left[\mathrm{F}(4-638)=5.150^{*} ; \mathrm{p}<.05\right]$. Just as it is in mother education status, in terms of father education status it can be said that the increase of the education level is one of the fundamental determiners within the increase of students' awareness regarding writing strategies and writing self-efficacies.

Table 5. The results of the variance analysis regarding the writing adequacies of the students according to the duration of daily book reading

\begin{tabular}{|c|c|c|c|c|c|c|c|c|c|c|c|}
\hline Dimensions & Duration & $\mathrm{n}$ & $M$ & ss & VK & $\mathrm{KT}$ & sd & $\mathrm{KO}$ & $\mathrm{F}$ & $\mathrm{p}$ & Difference \\
\hline \multirow{5}{*}{$\begin{array}{l}\text { Writing Strategies } \\
\text { Awareness }\end{array}$} & Never Read & 49 & 3.15 & .87 & Between & \multirow{2}{*}{23.916} & \multirow{2}{*}{3} & \multirow{2}{*}{7.972} & \multirow{5}{*}{$15.806^{*}$} & \multirow{5}{*}{.000} & \multirow{5}{*}{$\begin{array}{c}\text { Never Read and } \\
01-30,31-60,61 \text { and } \\
\text { more; } \\
01-30 \text { and } 31-60,61 \\
\text { and more }\end{array}$} \\
\hline & 01-30 min. & 306 & 3.62 & .72 & Groups & & & & & & \\
\hline & $61-60 \mathrm{~min}$. & 138 & 3.80 & .67 & & \multirow[b]{2}{*}{322.287} & \multirow[b]{2}{*}{639} & \multirow{3}{*}{.504} & & & \\
\hline & $\begin{array}{l}61 \text { min. and } \\
\text { more }\end{array}$ & 150 & 3,90 & .67 & Groups & & & & & & \\
\hline & Total & 643 & 3.69 & .73 & Total & 346.204 & 642 & & & & \\
\hline \multirow{5}{*}{$\begin{array}{l}\text { Writing } \\
\text { Self-Efficacy }\end{array}$} & Never Read & 49 & 3.26 & .65 & Between & \multirow{2}{*}{27.608} & \multirow{2}{*}{3} & \multirow{2}{*}{9.203} & \multirow{5}{*}{$22.576^{*}$} & \multirow{5}{*}{.000} & \multirow{5}{*}{$\begin{array}{c}\text { Never read and } \\
01-30,31-60,61 \text { and } \\
\text { more; } \\
\text { 01-30 and 31-60, } \\
\text { 61 and more }\end{array}$} \\
\hline & 01-30 min. & 306 & 3.77 & .67 & Groups & & & & & & \\
\hline & 61-60 min. & 138 & 4.02 & .59 & Within & & & & & & \\
\hline & $\begin{array}{l}61 \mathrm{~min} \text {. and } \\
\text { more }\end{array}$ & 150 & 4.03 & .61 & Groups & 260.480 & 639 & . 408 & & & \\
\hline & Total & 643 & 3.85 & .67 & Total & 288.088 & 642 & & & & \\
\hline \multirow{5}{*}{$\begin{array}{l}\text { Writing } \\
\text { Adequacies }\end{array}$} & Never Read & 49 & 3.20 & .71 & Between & \multirow{2}{*}{25.596} & \multirow{2}{*}{3} & \multirow{2}{*}{8.532} & \multirow{5}{*}{$21.247^{*}$} & \multirow{5}{*}{.000} & \multirow{5}{*}{$\begin{array}{c}\text { Never read and } \\
01-30,31-60,61 \text { and } \\
\text { more; } \\
\text { 01-30 and 31-60, } \\
\text { 61 and more }\end{array}$} \\
\hline & 01-30 min. & 306 & 3.70 & .66 & Groups & & & & & & \\
\hline & $61-60 \mathrm{~min}$ & 138 & 3.91 & .60 & Within & & & \multirow{3}{*}{2} & & & \\
\hline & $\begin{array}{l}61 \text { min. and } \\
\text { more }\end{array}$ & 150 & 3.96 & .59 & Groups & 256.607 & 639 & & & & \\
\hline & Total & 643 & 3.77 & .66 & Total & 282.203 & 642 & & & & \\
\hline
\end{tabular}

$* \mathrm{p}<.05$. 
Considering Table 5, it can be said that the writing strategy awareness of the students differentiate significantly in terms of daily book reading duration $\left[\mathrm{F}(3-639)=15.806^{*} ; \mathrm{p}<.05\right]$. Especially the writing strategies awareness of the students, who stated that they never read a book $(M=3.15)$ and those who read a book 01-30 min. $(M=3.62)$, are quite lower compared to others. Likewise their writing self-efficacies differentiate significantly $\left[\mathrm{F}(3-639)=22.576^{*} ; \mathrm{p}<.05\right]$. The students who never read a book $(M=3.26)$ and those who read a book 01-30 min. $(M=3.77)$ have lower writing self-efficacy compared to others. The findings of the research indicate that their writing adequacies differentiate significantly in terms of book reading durations $\left[\mathrm{F}(3-639)=21.247^{*} ; \mathrm{p}<.05\right]$. From this point of view it can be said that the increase in daily book reading durations affect both writing strategies awareness level and writing self-efficacy and also general perception level of writing adequacies in a positive way.

Table 6. The results of the variance analysis regarding the writing adequacies of the students according to daily watching TV

\begin{tabular}{|c|c|c|c|c|c|c|c|c|c|c|c|}
\hline Dimensions & Duration & $\mathrm{n}$ & $M$ & ss & VK & KT & $\mathrm{sd}$ & $\mathrm{KO}$ & $\mathrm{F}$ & $\mathrm{p}$ & Difference \\
\hline \multirow{4}{*}{$\begin{array}{l}\text { Writing } \\
\text { Awareness }\end{array}$} & $\min$ & 237 & 3.75 & .72 & & 3676 & 2 & 18 & \multirow{4}{*}{$3.434^{*}$} & \multirow{4}{*}{.033} & \multirow{4}{*}{$\begin{array}{l}121 \text { and more } \\
\text { ile } \\
0-60 \text {, } \\
61-120\end{array}$} \\
\hline & 61-120 min. & 185 & 3.73 & .73 & Groups & $.0 \%$ & 2 & \multirow{3}{*}{.535} & & & \\
\hline & $\begin{array}{l}121 \mathrm{~min} \text {. and } \\
\text { more }\end{array}$ & 221 & 3.59 & .75 & $\begin{array}{l}\text { Within } \\
\text { Groups }\end{array}$ & 342.528 & 640 & & & & \\
\hline & Total & 643 & 3.69 & .73 & Total & 346.204 & 642 & & & & \\
\hline \multirow{4}{*}{$\begin{array}{l}\text { Writing } \\
\text { Self-Efficacy }\end{array}$} & $\min$ & 237 & 3.92 & .63 & Between & 985 & 2 & 40 & \multirow{4}{*}{$3.350 *$} & \multirow{4}{*}{.036} & \multirow{4}{*}{$\begin{array}{l}0-60 \text { ile } 121 \text { and } \\
\text { more }\end{array}$} \\
\hline & $61-120 \mathrm{~min}$. & 185 & 3.86 & .68 & Groups & 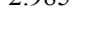 & 2 & & & & \\
\hline & $\begin{array}{l}121 \mathrm{~min} \text {. and } \\
\text { more }\end{array}$ & 221 & 3.76 & .70 & $\begin{array}{l}\text { Within } \\
\text { Groups }\end{array}$ & 285.103 & 640 & .445 & & & \\
\hline & Total & 643 & 3.85 & .67 & Total & 288.088 & 642 & & & & \\
\hline \multirow{4}{*}{ Writing Adequacies } & $\min$ & 237 & 3.84 & .63 & Between & 3272 & 2 & 1636 & & & \multirow{4}{*}{$\begin{array}{l}0-60 \text { ile } 121 \text { and } \\
\text { more }\end{array}$} \\
\hline & $61-120 \mathrm{~min}$. & 185 & 3.80 & .67 & Groups & .212 & 2 & .050 & & & \\
\hline & $\begin{array}{l}121 \mathrm{~min} \text {. and } \\
\text { more }\end{array}$ & 221 & 3.67 & .68 & $\begin{array}{l}\text { Within } \\
\text { Groups }\end{array}$ & 278.931 & 640 & .436 & $3.754 *$ & .024 & \\
\hline & Total & 643 & 3.77 & .66 & Total & 282.203 & 642 & & & & \\
\hline
\end{tabular}

$* \mathrm{p}<.05$.

Considering the findings in Table 6 , it is seen that daily watching TV duration variable differentiate significantly for writing strategies awareness $\left[\mathrm{F}(2-640)=3.434^{*} ; \mathrm{p}<.05\right]$. Especially it is seen that the writing strategies awareness of the students $(M=3.59)$, who watch TV $121 \mathrm{~min}$. and more, are lower than others. In addition research findings indicate that the duration of watching television is a reason for significant differentiation in terms of writing self-efficacies $[\mathrm{F}(2-640)=3.350 * ; \mathrm{p}<.05]$. Similarly the increase in the duration of watching television can be considered as a negative factor in terms of writing self-efficacies. Generally in terms of writing adequacies the duration of watching television variable is a significant differentiation reason $\left[\mathrm{F}(2-640)=3.754^{*} ; \mathrm{p}<.05\right]$. At the present time considering the time the children spend in front of television to what extent negative reflections will happen in terms of writing education will be revealed and concrete.

Table 7. The results of the variance analysis regarding students' writing adequacies according to daily use of Internet

\begin{tabular}{|c|c|c|c|c|c|c|c|c|c|c|c|}
\hline Dimensions & Duration & $\mathrm{n}$ & $M$ & ss & VK & KT & $\mathrm{sd}$ & $\mathrm{KO}$ & $\mathrm{F}$ & $\mathrm{p}$ & Difference \\
\hline \multirow{4}{*}{$\begin{array}{l}\text { Writing } \\
\text { Awareness }\end{array}$} & Never use & 201 & 3.65 & .77 & Between & \multirow{2}{*}{.596} & \multirow{2}{*}{2} & \multirow{2}{*}{.298} & \multirow{4}{*}{.552} & \multirow{4}{*}{.576} & \multirow{4}{*}{-} \\
\hline & 1 hour & 234 & 3.73 & .71 & Groups & & & & & & \\
\hline & $\begin{array}{c}2 \text { hours and } \\
\text { more }\end{array}$ & 208 & 3.69 & .73 & Within Groups & 345.607 & 640 & \multirow[t]{2}{*}{.540} & & & \\
\hline & Total & 643 & 3.84 & .73 & Total & 346.204 & 642 & & & & \\
\hline \multirow{4}{*}{ Writing Self-Efficacy } & Never use & 201 & 3.79 & .73 & Between & \multirow{2}{*}{1.374} & \multirow{2}{*}{2} & \multirow{2}{*}{.687} & \multirow{4}{*}{1.533} & \multirow{4}{*}{.217} & \multirow{4}{*}{-} \\
\hline & 1 hour & 234 & 3.90 & .64 & Groups & & & & & & \\
\hline & $\begin{array}{c}2 \text { hours and } \\
\text { more }\end{array}$ & 208 & 3.83 & .64 & Within Groups & 286.714 & 640 & \multirow[t]{2}{*}{.448} & & & \\
\hline & Total & 643 & 3.85 & .67 & Total & 288.088 & 642 & & & & \\
\hline
\end{tabular}




\begin{tabular}{|c|c|c|c|c|c|c|c|c|c|c|c|}
\hline \multirow{4}{*}{ Writing Adequacies } & Never use & 201 & 3.72 & .71 & Between & \multirow{2}{*}{.944} & \multirow{2}{*}{2} & \multirow{2}{*}{.872} & \multirow{4}{*}{1.074} & \multirow{4}{*}{.342} & \multirow{4}{*}{ 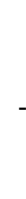 } \\
\hline & 1 hour & 234 & 3.81 & .64 & Groups & & & & & & \\
\hline & $\begin{array}{c}2 \text { hours and } \\
\text { more }\end{array}$ & 208 & 3.76 & .64 & Within Groups & 281.259 & 640 & \multirow[t]{2}{*}{.439} & & & \\
\hline & Total & 643 & 3.77 & .66 & Total & 282.203 & 642 & & & & \\
\hline
\end{tabular}

$* \mathrm{p}<.05$.

According to the findings in Table 7, the duration for the use of internet variable does not cause significant differentiation in terms of writing strategies awareness $[\mathrm{F}(2-640)=.552 ; \mathrm{p}>.05]$, writing self-efficacy $[\mathrm{F}(2-640)=1.533 ; \mathrm{p}>.05]$ and generally writing adequacy perception $[\mathrm{F}(2-640)=1.074 ; \mathrm{p}>.05]$. Considering this situation it can be said that unlike television the use of internet does not affect students' perceptions regarding writing.

Table 8 . The results of correlation analysis according to gender of the students

\begin{tabular}{lcccc}
\hline Dimensions & Gender & $\mathrm{n}$ & Writing Strategies Awareness & $\begin{array}{c}\text { Writing Skills } \\
\text { Self-Efficacy }\end{array}$ \\
\hline \multirow{2}{*}{ Writing Strategies Awareness } & Male & 308 & 1.00 & \\
& Total & 643 & 1.00 & 1.00 \\
\hline \multirow{2}{*}{ Writing Skills } & Female & 335 & $.77 * *$ & .80 \\
Self-Efficacy & Male & 308 & $.78 * *$ & 1.00 \\
& Total & 643 & & 1.00 \\
\hline
\end{tabular}

${ }^{*} \mathrm{p}<.05,{ }^{* *} \mathrm{p}<.01$.

The findings in Table 8 indicate that there are significant relations $(\mathrm{p}<.01$ and $\mathrm{p}<.05)$ between the writing strategies awareness and their writing self-efficacies of the female and male students. There is a positive relation in terms of both female $(\mathrm{r}=.77, \mathrm{p}<.01)$ and male students $(\mathrm{r}=.80, \mathrm{p}<.01)$. In addition it can be said that in terms of male students there is a small but higher relation compared to female students. In terms of all participants of the research there is a positive relation $(\mathrm{r}=.78, \mathrm{p}<.01)$.

Table 9. The results of correlation analysis according to grades of the students

\begin{tabular}{|c|c|c|c|c|}
\hline Dimensions & Department & $\mathrm{n}$ & Writing Strategies Awareness & $\begin{array}{l}\text { Writing Skills } \\
\text { Self-Efficacy }\end{array}$ \\
\hline \multirow{5}{*}{ Writing Strategies Awareness } & $5^{\text {th }}$ grade & 179 & 1.00 & \\
\hline & $6^{\text {th }}$ grade & 190 & 1.00 & \\
\hline & $7^{\text {th }}$ grade & 141 & 1.00 & \\
\hline & $8^{\text {th }}$ grade & 133 & 1.00 & \\
\hline & Total & 643 & 1.00 & \\
\hline \multirow{5}{*}{$\begin{array}{l}\text { Writing Skills } \\
\text { Self-Efficacy }\end{array}$} & $5^{\text {th }}$ grade & 179 & $.78 * *$ & 1.00 \\
\hline & $6^{\text {th }}$ grade & 190 & $.81 * *$ & 1.00 \\
\hline & $7^{\text {th }}$ grade & 141 & $.79 * *$ & 1.00 \\
\hline & $8^{\text {th }}$ grade & 133 & $.76^{* *}$ & 1.00 \\
\hline & Total & 643 & $.78 * *$ & 1.00 \\
\hline
\end{tabular}

$* \mathrm{p}<.05, * * \mathrm{p}<.01$

Table 9 reveals the correlational relations between writing strategies awareness levels and writing self-efficacies in terms of grade variable. At this point there are significant relations in every grade $(\mathrm{p}<.01$ and $\mathrm{p}<.05)$. Within the context of the research there are positive relations between writing strategies awareness levels and writing self-efficacy perceptions of the students in terms of 5 th grade $(\mathrm{r}=.78, \mathrm{p}<.01)$, 6th grade $(\mathrm{r}=.81, \mathrm{p}<.01), 7$ th grade $(\mathrm{r}=.79, \mathrm{p}<.01), 8$ th grade $(\mathrm{r}=.76, \mathrm{p}<.01)$ and all students $(\mathrm{r}=.78, \mathrm{p}<.01)$. Within the study the lowest correlational relation is at 8 th grade. 
Table 10. The results of the regression analysis between writing strategies awareness and writing self-efficacy levels

\begin{tabular}{lcccccc}
\hline Writing Skills Self-Efficacy & $\mathrm{n}$ & $\mathrm{B}$ & $\mathrm{SHB}$ & $\beta$ & $\mathrm{t}$ & $\mathrm{P}$ \\
\hline Stable & & 1.21 & .08 & & 14.36 & .00 \\
Writing Strategies Awareness & 643 & .71 & .02 & .78 & 31.86 & .00 \\
\hline $\mathrm{n}=643, \mathrm{R}=.78, \mathrm{R}^{2}=.61, \mathrm{~F}=1015.278, \mathrm{p}<.01$ & & & & \\
\hline
\end{tabular}

As a result of the simple linear regression analysis carried out in order to determine the predicting level of writing strategies awareness level on writing self-efficacy of the students, a significant relation was seen between these two variables $(\mathrm{R}=.78, \mathrm{R} 2=.61)$. Writing strategies awareness predict writing self-efficacy significantly $(\mathrm{F}(1-641)=$ $1015.278, \mathrm{p}<.01)$. At this point it can be said that writing strategies awareness explain $61 \%$ of the writing self-efficacy and 39\% part of the changes that belong to writing self-efficacy can be explained by other variables. The significance test of predictor variable coefficient $(B=.71)$ based on regression equation asserts that writing strategies awareness is a significant predictor. As a result of the linear regression analysis carried out the regression equation that predicts writing self-efficacy is: Writing Self-efficacy $=(.71 \mathrm{x}$ Writing Strategies Awareness $)+1.21$.

\section{Discussion}

In terms of gender variable within the context of the research it is determined that writing strategies awareness levels of the female students were higher than male students. This situation supports the experimental study carried out on writing performances of the university students (Amoush, 2015). Similarly the writing self-efficacies of the students differentiate significantly on behalf of the female students in terms of gender variable. Within the research carried out by Corkett, Hatt, and Benevides (2011) on 6th grade students it is indicated that the self-efficacies of the female students regarding writing were higher than male students. However in the research carried out on university students by Ningrum, Latief, and Sulistyo (2016) it was determined that there was not a significant difference in terms of gender variable considering learning styles.

In terms of grade variable writing strategies awareness levels decrease as the grade increases. Similarly writing self-efficacies differentiate significantly on behalf of especially 8th grades. It can be said that especially neglecting the process based on individual writing studies because of the transition system to the high school in the final year of the secondary school may be effective within this condition. It is generally compromised that teaching to write must be performed in a process based way which consist of prewriting, drafting, revising, editing, and publishing stages (Odom, 2009). The writing skill, which is the language talent that the students have difficulty is developed more slowly than other language skills and requires the use of various methods with exercises (Kuzu, 2016). When the literature regarding writing is examined it is seen that there is not an exact model that corresponds the processes used during the writing deed and on the contrary there are common operations (Sharp, 2016). However the qualitative study carried out by Dix and Cawkwell indicate that workshop based personal writing experiences increase the belief level for the self and low self-efficacy with the effect of peer reaction experience (2011). Naturally an unattended teacher's making a judgement and evaluation on a written piece of work is neither practical nor necessary (Austria, 2017). The attitudes of the students regarding writing, self-efficacy, and the connections between writing and success are important issues for the teacher (Hall \& Axelrod, 2014). If qualified education directives and applications that guide the writing success are not presented, and if they are directed to peer feedback with open writing studies, since the strength of the writing workshops/classes will decrease; teaching opportunities must be provided through various teaching strategies and ideas (Fisher \& Frey, 2006).

Mother and father education status differentiate significantly in terms of writing strategies awareness level and writing self-efficacies. Especially it is seen that it differentiates on behalf of the children whose parents graduated from university. Within the context of the research it is determined that daily book reading duration is a determiner both in the awareness levels regarding writing strategies and writing self-efficacy levels of the students. Especially it is determined that the writing awareness and writing self-efficacies of the students, who never read books or read a book till 30 minutes, are very low. In addition within the study in which the effect of inter-textual reading approach on creative writing studies is searched, it is indicated that it is very effective students' finding original ideas and possessing a rich vocabulary and utilize it in writing studies (Akdal \& Şahin, 2014).

Presently it is known that especially children watch TV excessively and they are seriously affected by what they watch. Within the context of the study it is determined that as daily watching TV duration increases the writing strategies awareness and writing self-efficacies of the students decrease seriously. Especially the children who watch TV for 2 or more hours have low levels of awareness and self-efficacy. While the known and shared emotional and social factors will enable concrete improvements in learning and teaching, the increase of students' 
awareness means that they will access better writing skills (Kathpalia \& Heah, 2011). Therefore it is very important to keep students away from watching TV excessively, which will avoid their social interaction, in terms of writing education. However within the research an effect was not determined in terms of daily use of internet. At the present day multimedia, web connected computers and the use of internet, present a series of informative communication and broadcasting devices that bring the world to the students (Pierson, 2014). Moreover it is known that the use of multimedia instructional materials has very important positive contributions to the writing education (Roscoe, Jocovina, Harry, Russell, \& Mcnamara, 2015). Also in a research carried out by Tanti it is indicated that digital correspondence can be used in the development of reading-writing skills (2012). In order to make teaching to read and write easier, teachers must consider the frame and reasons for including media in literacy activities, the most productive ways for learning, applications and the processes of integrating media into classes (Ross \& Linder, 2009). By this way both together with providing rich content for the written expressions of the students and having the opportunity of being in multicultural interactional environments teachers can provide effective learning opportunities for writing education.

Within the context of the research it is determined that there are positive relations between writing strategies awareness levels and writing self-efficacies of the secondary school students. Especially in male students this relation is higher compared to female students. Also as the grade increases it is seen that the relation level decreases even if it is weak. Within the research it is determined that writing strategies awareness levels is a significant predictor of writing self-efficacies in terms of secondary school students. On the other hand both in our country and in the world language education cannot avoid raising traditional readers-writers and the perception of the students is likewise (Wal \& Ryan, 2014). The research carried out by Nicholas, Menchetti \& Nettles indicates that using short structured written strategy education for African-American university students, who have learning difficulty, is effective for them to use supportive factors in their compositions (2005). In addition likewise the results of a research carried out on university students indicate that without considering the daily recording type that the students occupy with, there was a distinct improvement in self-efficacy of all students (Fritson, 2008). Also there are studies that indicate the students who have high writing anxiety have low levels of writing self-efficacy; the higher the writing attitude is the better writing adequacy will be (Singh \& Rajalingam, 2012; Ho, 2016). The interventions regarding decreasing the anxiety levels of the students and increasing their self-efficacies concerning writing, give positive results in students' use of meta-cognitive writing strategies and improves their written expressions (Stewart, Seifert, \& Rolheiser, 2015). When the students feel themselves motivated and supported they head for writing more ( $\mathrm{Li}, 2007)$. It is known that there is a positive relation between high self-efficacy and academic performance (Featonby, 2012). Likewise a study indicates that there is distinct difference within the writing studies of the students who have high self-efficacy (Bayraktar, 2013). Therefore the students, who have different cognitive talents, are expected to perform and arrange writing processes at different levels (Zare-ee \& Mahdavi, 2014). Since self-efficacy beliefs will affect the choices people make and the deeds that they practice as a reaction to their own decisions (Tai, 2016) it will provide a basis for the operation of the self-control process regarding performance. While self-control helps students at the point of understanding what a task, deed demand and how it can be learned in the best way; thus enable them to watch their own attitudes and deeds and develop their talents for arranging their needs to access the target (Jenson, 2011). Possessing a series of strategies may be useful but the important thing is making the strategy choice and use appropriately for the writing purposes and tasks (Maarof \& Murat, 2013). The purpose of teaching to write must be bringing ideas together for a subjective recreation, deciding what to say and turn these into a written product rather than developing to write in a mechanical way (Shea, 2015).

In conclusion in teaching to write adopting process based approaches and applications, directing to activity based paradigmatic lessons within teacher-student and student-student interaction and performing more activities regarding writing strategies will be effective for producing texts both in artistic and scientific platform concerning the writing skills of the students. It should not be forgotten that the belief level of the individual, who knows what to do in a complicated process like writing, concerning that she or he can achieve in the deed regarding writing performances will increase and this situation will reflect in his or her performance.

\section{References}

Ahn, H. (2012). Teaching writing skills based on a genre approach to 12 primary school students: an action research. English language teaching, 5(2), 2. https://doi.org/10.5539/elt.v5n2p2

Akdal, D., \& Şahin, A. (2014). The effects of intertextual reading approach on the development of creative writing skills. Eurasian journal of educational research, 54, 171-186. https://doi.org/10.14689/ejer.2014.54.10 
Amoush, K. H. (2015). The impact of employing brainstorming strategy on improving writing performance of English major students at balqa applied university in jordan. Journal of education and practice, 6(35), 88-92. www.iiste.org

Asmari, A. A. (2013). Investigation of writing strategies, writing apprehension, and writing achievement among Saudi efl-major students. International education studies. 6(11), 130-143. https://doi.org/10.5539/ies.v6n11p130

Austria, M. A. B. (2017). Peer response as an effective writing strategy. International journal of progressive education, 13(2).

Bahaziq, A. (2016). Cohesive devices in written discourse: a discourse analysis of a student's essay writing. English language teaching, 9(7), 112. https://doi.org/10.5539/elt.v9n7p112

Bandura, A. (1994). Self efficacy. (V. S. Ramachaudran, ed.). Enclopedis of human behavior, 4, 71-81. New York: Academic Press.

Barhes, R. (2003). Yazının sıfir derecesi (Translated by T. Yücel). Metis Yayınları, İstanbul.

Bayraktar, A. (2013). Nature of interactions during teacher-student writing conferences, revisiting the potential effects of self-efficacy beliefs. Eurasian journal of educational research, 50, 63-85.

Bayraktar, H. V. (2016). Examination of the self-efficacy of primary school teacher candidates towards first reading-writing education. Higher education studies, 6(4), 119-130. https://doi.org/10.5539/hes.v6n4p119

Bodnar, J. R., \& Petrucelli, S. L. (2016). Strengthening academic writing. NADE digest, 9(1), 40-43.

Burke, L., Poll, G., \& Fiene, J. (2017). Response to an expository writing strategy across middle school RTI tiers. Learning disabilities: a contemporary journal, 15(1), 85-101.

Büyüköztürk, Ş., Çakmak, E. K., Akgün, Ö. E., Karadeniz, Ş., \& Demirel, F. (2014). Bilimsel araştırma yöntemleri. Pegem Akademi, Ankara.

Chomsky, N. (2009). Bilgi sorunları ve dil: managua dersleri (Translated by V. Kılıç). bgst Yayınları, İstanbul.

Corkett, J., Hatt, B., \& Benevides, T. (2011). Student and teacher self-efficacy and the connection to reading and writing. Canadian journal of education, 34(1), 65-98.

Cramer, A. M., \& Mason, L. H. (2014). The effects of strategy instruction for writing and revising persuasive quick writes for middle school students with emotional and behavioral disorders. Behavioral disorders, 40(1), 37-51. https://doi.org/10.17988/0198-7429-40.1.37

Creswell, J. W. (2016). Araştırma deseni: nitel, nicel ve karma yöntem yaklaşımları (Translated by S. B. Demir). Eğiten Kitap, Ankara.

Dix, S., \& Cawkwell, G. (2011). The influence of peer group response: Building a teacher and student expertise in the writing classroom. English teaching: practice and critique, 10(4), 41.

Faull, T. (2007). Writing in a-level English literature essays: professional reflections on text organisation. English teaching: Practice and critique, 6(1), 164. Retrieved from http://education.waikato.ac.nz/research/files/etpc/2007v6n1nar1.pdf

Featonby, A. (2012). The use of the 'teaching as inquiry model' to develop students' self-efficacy in literature response essay writing. Weaving educational threads. Weaving educational practice. Kairaranga, 13(1), 24-35.

Fisher, D., \& Frey, N. (2006). Writing ideas that work. The language and literacy spectrum, 16, 33-40.

Fritson, K. K. (2008). Impact of journaling on students' self-efficacy and locus of control. Insight: A journal of scholarly teaching, 3, 75-83.

Gagnon, R., \& Ziarko, H. (2012). The writing of expository texts in early grades: what predicative analysis teaches us. US-China education review a, 10, 885-891.

Gulley, B. (2012). Feedback on developmental writing students' first drafts. Journal of developmental education, $36(1), 16$.

Güneş, F. (2007). Türkçe öğretimi ve zihinsel yapılandırma. Nobel, Ankara.

Hall, A. H., \& Axelrod, Y. (2014). "I am kind of a good writer and kind of not": examining students' writing attitudes. Journal of research in education, 24(2). 
Ho, M. (2016). Exploring writing anxiety and self-efficacy among EFL graduate students in Taiwan. Higher education studies, 6(1), 24. https://doi.org/10.5539/hes.v6n1p24

Horn, S. K. (2007). Motivating basic writers through self-assessment and goal-setting. NADE digest, 3(2), 1-11.

Jacobs, G. M., \& Yang, S. T. H. (2004). Using cooperative learning to teach via text types. The reading matrix, $4(2)$.

Jenson, J. D. (2011). Promoting self-regulation and critical reflection through writing students' use of electronic portfolio. International journal of eportfolio, 1(1), 49-60.

Jones, S. (2007). "Composing in the style of Mozart: An exploration of the "struggling boy writer" comparing the composing processes and strategies of boys and girls. English teaching: practice and critique, 6(1), 96-112. Retrieved from http://education.waikato.ac.nz/research/files/etpc/2007v6n1art5.pdf

Kathpalia, S. S., \& Heah, C. (2011). Affective and social factors in a project-based writing course. i-Manager's journal on English language teaching, 1(1), 20.

Kuzu, T. S. (2016). The impact of a semiotic analysis theory-based writing activity on students' writing skills. Eurasian journal of educational research, 16(63). https://doi.org/10.14689/ejer.2016.63.3

Lan, Y. F., Hung, C. L., \& Hsu, H. J. (2011). Effects of guided writing strategies on students' writing attitudes based on media richness theory. TOJET: The Turkish online journal of educational technology, 10(4).

Laud, L. E., \& Patel, P. (2008). Teach struggling writers to unite their paragraphs. Teaching exceptional children plus, 5(1), n1. Retrieved from http://escholarship.bc.edu/education/tecplus/vol5/iss1/art4

Li, L. Y. (2007). Exploring the Use of Focused Freewriting in Developing Academic Writing. Journal of University Teaching and Learning Practice, 4(1), 5. Retrieved from http://ro.uow.edu.au/jutlp/vol4/iss1/5

Luna, A. M. R., \& Ortiz, L. S. H. (2013). Collaborative writing to enhance academic writing development through project work. HOW, a Colombian journal for teachers of English, 20(1), 130-148. Bogotá, Colombia.

Maarof, N., \& Murat, M. (2013). Writing strategies used by ESL upper secondary school students. International education studies, 6(4), 47. https://doi.org/10.5539/ies.v6n4p47

Mageehon, A. (2011). Play as a method of engaging students in developmental writing. NADE Digest, 5(3), 61-69.

Mahnam, L., \& Nejadansari, D. (2012). The effects of different pre-writing strategies on Iranian EFL writing achievement. International education studies, 5(1), 154. https://doi.org/10.5539/ies.v5n1p154

Mango, C. (2009). Self-regulation and approaches to learning in English composition writing. TESOL journal, $1(3)$.

Martinet, A. (1998). İşlevsel genel dilbilim (Translated by B. Vardar). Multilingual, İstanbul.

Nelson, A., Schmidt, J., \& Verbais, C. (2006). Boosting Imagination: Incorporating Creative Play into the Writing Room. NADE Digest, 2(2), 19-26.

Nicholas, K. R., Menchetti, B. M., \& Nettles, S. M. (2005). An exploratory investigation of structured writing strategy training for African-American college students with learning disabilities. Journal of college reading and learning, 36(1), 37-59. https://doi.org/10.1080/10790195.2005.10850179

Ningrum, A. S. B., Latief, M. A., \& Sulistyo, G. H. (2016). The effect of mind mapping on EFL students' idea development in argumentative writing across gender differences and learning styles. Dinamika ilmu, 16(1), 149-166.

Ockerstrom, L. (2007). Positive expectations: A reflective tale on the teaching of writing. InSight: A collection of faculty scholarship, 2, 50-56.

Odom, J. M. (2009). Heuristics in the English classroom: working the problem of drafting the research paper. The CEA forum, 38(1).

Ong, W. J. (2014). Sözlü ve yazılı kültür: sözün teknolojileşmesi (Translated by S. P. Banon). Metis Yayınları, İstanbul.

Penny, U. (1998). A course in language teaching: practice and theory. Cambridge University Press, United Kingdom.

Pierson, S. J. (2014). The power of story: using personal narrative, computer technology and podcasting with 
young adult English language learners. Teaching English with technology, 14(4), 3-16.

Roscoe, R. D., Jocovina, M. E., Harry, D., Russell, D. G., \& Mcnamara, D. S. (2015). Partial Verbal Redundancy in Multimedia Presentations for Writing Strategy Instruction. Applied Cognitive Psychology, 29(5), 669-679. https://doi.org/10.1002/acp.3149

Ross, F. F., \& Linder, R. (2009). Reading and writing connections using media: addressing the literacy needs of students in intermediate and middle level classrooms. The language and literacy spectrum, 19, 29-38.

Saito, H. (1994). Teachers' practices and students' preferences for feedback on second language writing: a case study of adult ESL learners. TESL Canada journal/revue TESL du Canada, 11(2), 46-70. https://doi.org/10.18806/tesl.v11i2.633

Saussure, F. de. (1998). Genel dilbilim dersleri (Translated by B. Vardar). Multilingual, İstanbul.

Shafiee, S., Koosha, M., \& Afghari, A. (2015). CALL, prewriting strategies, and EFL writing quantity. English Language Teaching, 8(2), 170. https://doi.org/10.5539/elt.v8n2p170

Sharp, L. A. (2016). Acts of writing: A compilation of six models that define the processes of writing. International journal of instruction, 9(2), 77-90. https://doi.org/10.12973/iji.2016.926a

Shea, M. (2015). Differentiating writing instruction: meeting the diverse needs of authors in a classroom. Journal of inquiry and action in education, 6(2), 4.

Singh, T. K. R., \& Rajalingam, S. K. (2012). The relationship of writing apprehension level and self-efficacy beliefs on writing proficiency level among pre-university students. English language teaching, 5(7), 42.

Stewart, G., Seifert, T. A., \& Rolheiser, C. (2015). Anxiety and self-efficacy's relationship with undergraduate students' perceptions of the use of metacognitive writing strategies. The Canadian journal for the scholarship of teaching and learning, 6(1), 4.

Sumarsih, M. Pd., \& Sanjaya, D. (2013). TPS as an effective technique to enhance the students' achievement on writing descriptive text. English language teaching, 6(12), 106. https://doi.org/10.5539/elt.v6n12p106

Tai, H. C. (2016). Effects of collaborative online learning on EFL leaners' writing performance and self-efficacy. English language teaching, 9(5), 119-133. https://doi.org/10.5539/elt.v9n5p119

Tan, H., \& Eng W. B. (2014). Metadiscourse use in the persuasive writing of Malaysian undergraduate students. English language teaching, 7(7), 26-39. https://doi.org/10.5539/elt.v7n7p26

Tanti, M. (2012). Literacy education in the digital age: Using blogging to teach writing. Teaching English with technology, 12(2), 132-146.

Van Kooten, C. (2016). Identifying components of meta-awareness about composition: toward a theory and methodology for writing studies. Composition forum, 33(1). Retrieved from https://files.eric.ed.gov/fulltext/EJ1092005.pdf

Vardi, I. (2009). The relationship between feedback and change in tertiary student writing in the disciplines. International journal of teaching and learning in higher education, 20(3), 350-361.

Wal, L. V. D., \& Ryan, T. G. (2014). Student perceptions of literacy after the ontario secondary literacy course: A qualitative inquiry. Brock education, 20(3), 350-361.

Webb, R. K. (2015). Teaching English writing for a global context: an examination of NS, ESL and EFL learning strategies that work. PASAA: journal of Language teaching and learning in Thailand, 49, 171-198.

Yamini, M., \& Mandanizadeh, F. B. (2011). Relationship between EFL learners' self-efficacy and imposter phenımenon and their effects on learners' writing ability. Advances in language and literary studies, 2(1), 70-80. https://doi.org/10.7575/aiac.alls.v.2n.1p.70

Yoo, J. (2014). The value of aesthetic teacher learning: drawing a parallel between the teaching and writing process. Australian journal of teacher education, 39(9), 9. https://doi.org/10.14221/ajte.2014v39n9.6

Zare-ee, A., \& Mahdavi, F. (2014). Researching aptitude in a process-based approach to foreign language writing instruction. Advances in language and literary studies, 5(5), 22-27. 


\section{Copyrights}

Copyright for this article is retained by the author(s), with first publication rights granted to the journal.

This is an open-access article distributed under the terms and conditions of the Creative Commons Attribution license (http://creativecommons.org/licenses/by/4.0/). 